\title{
ONDANSETRONA ORAL NA PREVENÇÃO DE NÁUSEAS E VÔMITOS PÓS-OPERATÓRIOS
}

\author{
Elaine Milani Lewaschiw, Irla Abadia Pereira, José luiz Gomes do Amaral* \\ Trabalho realizado na disciplina de Anestesiologia, Dor e Terapia Intensiva do \\ Departamento de Cirurgia da Universidade Federal de São Paulo, SP
}

RESUMO - Objetivos. Em passado não remoto, a incidência de náuseas e vômitos no pós-operatório (NVPO) ainda alcançava $40 \%$ a $50 \%$. Publicaçōes mais recentes indicam que a freqüência desta complicaçáo ainda é considerável: $20 \%$ a $30 \%$. 0 presente estudo teve como objetivo avaliar, em pacientes submetidos à anestesia geral, o impacto da administração oral de ondansetrona na incidência de NVPO.

Métodos. Foram incluídos 178 pacientes em estudo prospectivo, randomizado, controlado e duplo-cego, divididos em dois grupos (ondansetrona $=89$ e placebo $=89$ ), utilizando. se comprimidos de dissolução oral rápida, especialmente prepa. rados para este estudo. A medicação foi administrada entre 30 e 60 minutos antes da indução anestésica. Anotou-se fatores que pudessem influenciar 0 evento, como gênero, idade, antecedentes de discinesia ou NYPO, tabagismo, tipo de cirurgia, índice de massa corpórea, reversão do bloqueio neuromuscular com neostigmine e intensidade da dor pós-operatória.

REsultados. Näo houve diferença significativa entre os grupos referentes aos fatores anotados, exceto tabagismo e índice de massa corpórea, que prevaleceu no grupo placebo. Estes fatores não interferiram na análise dos resultados. Observou-se NVPO em 23 (26\%) pacientes do grupo ondansetrona e 38 (43\%) pacientes do grupo placebo $(p<0,05)$.

Conclusoes. A ondansetrona, $16 \mathrm{mg}$ por via oral, administrada no pré-operatório reduz significativamente a incidência de náuseas e vômitos no pós-operatório. A simplicidade de administraçăo e 0 baixo custo desta apresentação justificam a opção por esta via de administração.

Unitermos: Náuseas. Vômitos. Antieméticos. Ondansetrona.

\section{INTRODUÇÃO}

Náuseas e vômitos no pós-operatório (NVPO) - fenômenos referidos como "os grandes pequenos problemas" - em passado não remoto alcançavam elevada incidência: $28,5 \%$ a $80 \%$ para náuseas e $50 \%$ a $66 \%$ 2,3 para vômitos. Publicações mais recentes indicam que a freqüência desta complicação ainda é considerável: $20 \%$ a $30 \%$, 4.5 podendo atingir $54 \%$ em amigdalectomias infantis 6 e variando de $50 \%$ a $56 \%$ em procedimentos laparoscópicos $7,8,9$. Este fato deve-se provavelmente ao impacto positivo de mudanças na prática anestésica. Aqui, entre outros avanços relevantes, destacam-se a atenção ao controle da ansiedade pré-operatória, a analgesia pósoperatória e a introdução de novos agentes anestésicos. Ainda assim, e, sobretudo na presença de fatores predisponentes, justifica-se considerar a administração profilática de antieméticos.

Durante anos, NVPO foram considerados efeitos inerentes à aplicação de anestésicos ou

\footnotetext{
* Correspondência:

Disciplina de Anestesiologia, Dor e Terapia Intensiva

Rua Napoleão de Barros, $715-4^{\circ}$ andar CEP: 04024-900 - São Paulo - SP

Tel/Fax: $\quad 5576-4069$
}

complicações "menores" da anestesia ${ }^{10}$. Entretanto, deste problema originam-se diversos outros: hipocalemia, alcalose hipoclorêmica, desidratação, Síndrome de Mallory-Weiss, broncoaspiração", deiscência de suturas' ${ }^{12}$, sangramento intraocular e cutâneo, admissão hospitalar após cirurgias ambulatoriais ${ }^{13}$, desconforto psicológico e prolongamento da internação ${ }^{14}$, com aumento de custos, tanto para o hospital como para o paciente ${ }^{15}$.

Intervenções físicas, como acupuntura ${ }^{16}$, acupressão ${ }^{17,18}$, estimulaçãa de baixa-freqüên$\mathrm{cia}^{19}$, bem como diversos agentes farmacológicos como os fenotiazínicos proclorperazina $^{20-22}$, prometazina ${ }^{23-25}$ e perfenazina ${ }^{26,27}$; os butirofenônicos haloperido|28-31 e droperido 25,32-39; os anti-histamínicos difenidramina (dimenidrato) $^{40,41}$; hidroxizina ${ }^{42,43}$ e ciclizina ${ }^{4447}$; dentre os anticolinérgicos, a escopolamina ${ }^{23,4850 ;}$ os benzamídicos como a metoclopramida $33,37,51-57$ e domperidona ${ }^{33,37,58-61}$; a alizaprida ${ }^{62-65}$; os corticosteróides ${ }^{33,66-76}$; a efedrina ${ }^{77}$; o propo-

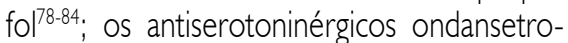
$n a^{8,13,20,39,41,45,46,56,81,85-97}$, a granisetrona ${ }^{66,67,98-100}$ e a tropisetrona ${ }^{93,96,101-103, ;}$ a ramosentrona ${ }^{100} \mathrm{e}$ a dolasetrona ${ }^{104}$ têm sido empregados com sucesso na prevenção de NVPO.

Dessas múltiplas possibilidades, a ondansetrona, pela efetividade ${ }^{88,92}$ e menores efeitos colaterais $3,8,13,86,91$, encontra-se entre os agentes mais largamente empregados no controle de NVPO. Apesar de apresentar resultado mais eficaz que a metoclopramida 3,7,13,56,85,87,91,105, o custo elevado das preparações intravenosas de ondansetrona tem ainda limitado sua utilização $81,106,107$.

Assim, considerando as características farmacocinéticas favoráveis ${ }^{108,109}$, o menor custo e a conveniência da administração oral, busca-se, através deste estudo, avaliar a efetividade da ondansetrona oral na prevenção de NVPO.

\section{Objetivo}

O presente estudo tem como objetivo avaliar, em pacientes submetidos à anestesia geral, o impacto da administração oral de ondansetrona na incidência de náuseas e vômitos no pós-operatório imediato.

\section{Métodos}

Trata-se de um estudo clínico controlado, comparativo, randomizado e duplo cego.

Após aprovação da pesquisa pelo Comitê de Ética do Hospital São Paulo - Escola Paulista de Medicina/UNIFESP, e da assinatura do consentimento pós-informado, foram incluídos 
no estudo 278 pacientes com idade entre 8 e 40 anos, candidatos a uma das seguintes cirurgias: oftalmológica, otorrinolaringológica, ginecológica abdominal ou abdominal videoassistida. Não foram incluídos pacientes com intolerância à ondansetrona e, posteriormente à inclusão, foram excluídos os submetidos a anestesia com duração além de 3 horas e aqueles em quem não foi possível aplicar integralmente o presente protocolo.

Tanto a ondansetrona quanto o placebo utilizados foram formulados em comprimidos de dissolução oral instantânea, de forma que sua utilização não interferisse no jejum préoperatório. Essas formulações, às quais se acrescentou sabor morango, foi especialmente produzida para este estudo (Vonan Dissolução Instantânea, Biolab Sanus Indústria ${ }^{\circledR}$ Farmacêutica Ltda).

As preparações de ondansetrona (16 mg) ou placebo foram veiculadas em envelopes identificados através de código numérico e administradas via oral entre 30 e 60 minutos antes da anestesia. Elas foram divididas em lotes de 20 unidades, contendo em igual número os que possuem ondansetrona ou placebo. Os investigadores apenas conheceram a natureza das preparações ao abrirem os envelopes de decodificação da medicação. Foram assim constituídos os dois grupos de estudo, grupo $\mathrm{O}$ (ondansetrona) e grupo $\mathrm{P}$ (placebo).

A avaliação e preparo pré-operatórios, a assistência anestésica, bem como os cuidados pós-operatórios, foram semelhantes a todos os pacientes incluídos neste estudo, não diferindo da rotina adotada no Serviço. Adotou-se a monitorização rotineiramente indicada para as situações clínicas que se apresentaram, constando de cardioscopia, oximetria de pulso e esfigmomanometria automática. Todos os pacientes foram intubados e ventilados mecanicamente no intraoperatório. Beneficiaram-se de anestesia balanceada, incluindo isoflurano, opióides e bloqueadores neuromusculares adespolarizantes. A hidratação e reposição volêmica foram providas com solução salina. Ao final do procedimento, interrompeu-se a administração dos agentes inalatórios, reverteu-se, quando necessário, o bloqueio neuromuscular com neostigmina precedida de atropinização. Uma vez as condições clínicas encontrando-se estáveis e satisfatórias, procedeu-se a desintubação, sendo o paciente

\begin{tabular}{|c|c|c|c|c|}
\hline \multicolumn{5}{|c|}{ 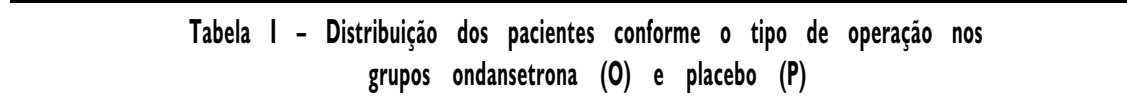 } \\
\hline Tipo de operação & Grupo 0 & Grupo $P$ & $p$ & Total \\
\hline Otorrinolaringológica & 55 & 49 & $\overline{0,45}$ & 104 \\
\hline Oftalmológica & 10 & 10 & 0,81 & 20 \\
\hline Videolaparoscópica & 21 & 28 & 0,31 & 49 \\
\hline Ginecológica abdominal & 03 & 02 & 1,00 & 05 \\
\hline Total & 89 & 89 & - - & 178 \\
\hline
\end{tabular}

\begin{tabular}{lccccc}
\hline Tabela 2 - Distribuição dos pacientes de acordo com os fatores que pudessem influenciar \\
NVPO
\end{tabular}

${ }^{a}$ Valores expressos pela Média \pm Desvio padrão; $\mathrm{O}=$ Ondansetrona; $\mathrm{P}=$ Placebo; * Valores considerados significativos

encaminhado à sala de recuperação pósanestésica. Daí os doentes foram levados para as enfermarias e acompanhados durante 12 horas.

A aplicação deste protocolo de pesquisa não afetou negativamente o tratamento anestésico ou cirúrgico proposto em função da situação clínica dos pacientes nele incluídos, assim como não trouxe risco ou desconforto.

O estado físico da população estudada foi caracterizado conforme a classificação proposta pela Sociedade Americana de Anestesiolgistas. Foi avaliada a incidência de náuseas e vômitos pós-operatórios, anotados os fatores que se conhecem possam influenciar o evento em questão. Incluem-se aqui gênero, idade, antecedentes de discinesia ou NVPO, tabagismo, local da operação (como cirurgia abdominal, extra-abdominal, do ouvido médio, e instrumentação/manipulação dos músculos extrínsecos do olho), o índice de massa corporal, a intensidade da dor pós-operatória e a reversão do bloqueio neuromuscular com neostigmina. Estas associações, voltadas para a comparabilidade dos grupos de estudo, bem como a comparação dos efeitos da ondasetrona com os do placebo, foram estudadas por meio de análise de variância (teste-t; para dados intervalares) e de contingência (Qui-quadrado; para variáveis nominais).

\section{Resultados}

Cento e setenta e oito pacientes fizeram parte da avaliação final, 89 em cada um dos grupos de estudo.

Não houve diferença significativa entre os grupos com relação ao tipo de operação (Tabela I), à idade, gênero, estado físico (ASA), antecedente de discinesia, tratamento com neostigmina e intensidade máxima de dor pós-operatória (Tabela 2). No grupo $\mathrm{P}$ 


\begin{tabular}{lcccc}
\hline Tabela 3 - Distribuição dos pacientes conforme incidência de NVPO nos grupos \\
ondansetrona & $(\mathbf{0})$ e placebo $(\mathbf{P}) \quad(p=0,04)$ & \\
\hline NVPO & $\frac{\text { Grupo } O(n=89)}{23(26 \%)}$ & $\frac{\text { Grupo } P(n=89)}{38(43 \%)}$ & $\frac{\text { Total }}{61(34 \%)}$ & $\frac{\text { Signnificância }}{p=0,04}$ \\
\hline
\end{tabular}

Gráfico I - Incidência $(\%)$ de NVPO nos pacientes tratados com ondansetrona ou placebo $(n=\mid 78)$

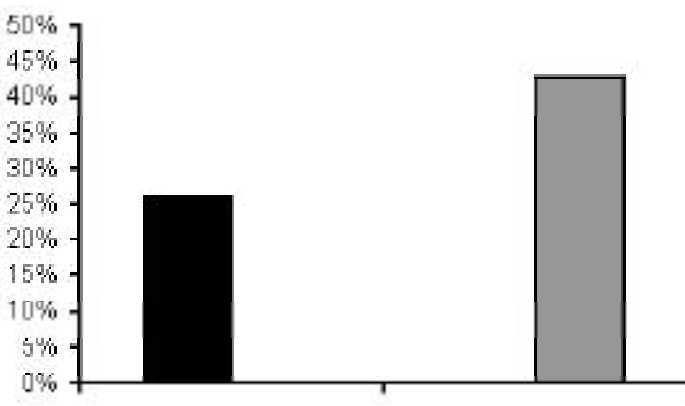

encontrou-se maior incidência de tabagismo que no grupo $\bigcirc(13 \times 04$ pacientes; $p=0,04)$ e o índice de massa corporal foi discretamente maior no grupo $P(23 \pm 5 \times 21 \pm 4 ; p=0,05)$.

Em 61 pacientes observou-se NVPO. Eles distribuíram-se 23 no Grupo $\bigcirc 38$ no Grupo P. Assim, a incidência de NVPO no grupo tratado com ondansetrona oral foi $26 \%$, enquanto, no grupo placebo, alcançou 43\%, e esta diferença mostrou-se significante $(p=0,04)$ (Tabela 3 e Gráfico I). Nenhum dos pacientes referiu cefaléia.

\section{Discussão}

A ondansetrona intravenosa, administrada no pré-operatório ou no intra-operatório tem-se mostrado eficaz na prevenção de NVPO tanto em adultos como em crianças $8,13,56,85,87,89-92,110,111$. São, todavia, relativamente poucos os estudos que tratam da eficácia da ondansetrona oral na prevenção de NVPO6,7,112-117. No presente estudo, buscou-se confirmar a eficácia da administração oral pré-operatória deste fármaco em intervenções com duração não superior a 3 horas. Ele foi, portanto, aplicado em uma população de maior risco de NVPO, incluídos nele pacientes que se beneficiaram de operações otorrinolaringológicas, oftalmológicas, videolaparoscópicas e ginecológicas abertas. A maioria dos pacientes era do gênero feminino ( 110 mulheres e 68 homens). Os grupos de estudo foram comparáveis com relação aos fatores de risco para NVPO exceto no que tange ao tabagismo. O impacto do tabagismo nos resultados não favoreceu o grupo tratado com ondansetrona ${ }^{14,118}$, visto que se encontrou maior incidência de tabagistas no grupo placebo, onde esta complicação foi mais freqüentemente encontrada. Apesar de termos uma diferença estatisticamente significante em relação ao IMC, que foi superior no grupo $P$, esta desigualdade não foi clinicamente significante.

Aondansetrona é completa e rapidamente absorvida no trato gastrintestinal, e não apresenta efeito acumulativo após repetidas doses. Apresenta biodisponibilidade de 59\% a 67\% após a primeira passagem ${ }^{109,119}$. $\bigcirc$ pico de concentração plasmática é de meia a duas horas após a ingestão. Isto é insignificantemente aumentado quando a ondansetrona é administrada após uma refeição e não é influenciado por administração concomitante com antiácidos. A ondansetrona é amplamente distribuída (seu volume de distribuição é de aproximadamente 160 L) e possui ligação protéica moderada (70\% a é metabolizada no fígado e eliminada via renal. Os metabólitos não são ativos ${ }^{108}$.

A opção por via oral no pré-operatório requer a solução de três problemas:

I) Garantir níveis plasmáticos de ondansetrona adequados após a passagem hepática;

2) Garantir que estes níveis estejam presentes no pós-operatório imediato, e que não tenham decaído a ponto de se tornarem inefetivos; $76 \%$ ). Noventa e cinco por cento da droga
3) Evitar acrescentar volume relevante ao conteúdo gástrico.

Em voluntários normais, encontrou-se, após injeção intravenosa de $8 \mathrm{mg}$, pico de concentração plasmática entre 67,9 e 139,9 ng/mL, meia-vida de eliminação entre 2,7 e 5,8 $h^{119,120}$ e depuração plasmática entre 0,262 e 0,381 $\mathrm{L} / \mathrm{h} / \mathrm{kg}^{108}$. Após a administração oral de 8 mg, encontrou-se pico de concentração plasmática entre 22,0 e 48,4 ng/mL, e tempo máximo para pico de concentração plasmática entre 1,7 e 2,2h. A meia-vida de eliminação oscilou entre 2,4 e 5,8 $h^{119,120}$, e a depuração plasmática de $0,249 \mathrm{a} 0,403 \mathrm{~L} / \mathrm{h} / \mathrm{kg}^{108}$. Os picos de concentração plasmática tendem a ser mais elevados e a depuração mais lenta em idosos ${ }^{108,120}$ e nas mulheres ${ }^{108}$. Assim, a disponibilidade de $16 \mathrm{mg}$ deste fármaco após a administração oral equivale a $8 \mathrm{mg}$ em injeção intravenosa ${ }^{108}$. Em razão do exposto, nesta investigação optou-se por veicular a ondansetrona em comprimidos de dissolução instantânea e definiu-se 16 mg de ondansetrona, dose que se mostrou efetiva no presente estudo e em outros encontrados na literatura||12,114,116.

\section{CONCLUSÃo}

Ondansetrona, 16 mg, por via oral, administrada no pré-operatório reduz significativamente a incidência de náuseas e vômitos pósoperatórios.

Em relação à apresentação parenteral, a efetividade, o baixo custo e a simplicidade de administração da apresentação de ondansetrona de dissolução rápida para uso oral, bem como sua ampla aceitação tanto por pacientes adultos como pediátricos devido ao agradável sabor morango, justificam a opção por esta via de administração.

\section{Conflito de interesse: não há.}

\section{SUMmary}

\section{THE EFFECT OF ORAL ONDANSETRON IN THE PREVENTION OF POSTOPERATIVE NÁUSEA AND VOMITING}

ObJECTIVES. Not so many years ago, the incidence of postoperative nausea and vomiting used to reach $40 \%$ to $50 \%$. More recent publications indicate that this complication still reaches considerable frequency: 20 to 30\%. The present study had the objective of evaluating the impact of oral administration of ondansetron on the incidence ofpostoperative 
nausea and vomiting among patients submitted to general anesthesia.

Methods. This was a prospective, randomized, controlled, double-blind study. It included I 78 patients divided into two groups: Ondansetron $(n=89)$ and Placebo $(n=89)$. Fast-disso Iving oral tablets specially prepared for this study were utilized. The medication was administered between 60 and 30 minutes before anesthesia was induced. Factors with possible influence on the event were noted down, such as gender, age, history of dyskinesia or postoperative nausea and vomiting, smoking, type of surgery, body mass index, reversal of neuromuscularblockade using neostigmine, and the severity of postoperative pain.

RESULTS. There was no significant difference between the characteristics of the groups regarding the factors annotated, except in relation to smoking and body mass index, which were greater in the Placebo group. These factors did not interfere in the analysis of the results. Postoperative nausea and vomiting were observed in 23 patients (26\%) of the Ondansetron group and 38 patients (43\%) of the Placebo $\operatorname{group}(p<0.05)$.

Conclusions. Ondansetron, 16 mg orally, administered before the operation significantly reduced the incidence of postoperative nausea and vomiting. The simplicity of administration and low cost of this presentation justify the choice of this administration route. [Rev Assoc Med Bras 2005; 5 I (I): 35-40]

KEY wORDS: Nausea. Vomiting. Antiemetics. Ondansetron.

\section{REFERÊNCIAS}

I. Kapur PA. The big "little problem". Anesth Analg | 991;73:243-5.

2. Van Oss GECJM, Rachmat Y, Booij LHDJ, Crull JF. Continuous infusion of etomidate as a method for out patient anesthesia. Acta Anaesthesiol Belg 1980;3 I ( ):39-44.

3. Martins RS, Martins ALC, Grillo F, Bortolozzo CR. Prevenção de náuseas e vômitos no pósoperatório com ondansetron: comparação com prometazina. Rev Bras Anestesiol 1995;45(4):253-8.

4. Watcha MF, White PF. Postoperative nausea and vomiting. Its etiology, treatment and prevention. Anesthesiology 1992; 77: 162-84.

5. Kovac AL. Prevention and treatment of postoperative nausea and vomiting. Drugs 2000;59(2):213-43.

6. Splinter WM, Baxter MRN, Gould HM, Hall LE. Oral ondansetrona decreases vomiting after tonsillectomy in children. Can J Anaesth 1995; 42(4): 277.

7. Malins AF, Field JM, Nesling PM, Cooper GM. Nausea and vomiting after gynaecological laparoscopy: comparison of premedication with oral ondansetrona, metoclopramide and placebo. Br J Anaesth 1994; 72(2):23 I-3.

8. Suen TKL, Gin TA, Chen PP, Rowbottom YM, Critchley LAH, Ray AK. Ondansetron 4 mg for the prevention of nausea and vomiting after minor laparoscopic gynaecological surgery. Anesth Intensive Care 1994;22: | 42-6.

9. Watts SA. A randomized double-blinded comparison of metoclopramide, ondansetron and cyclizine in day-case laparoscopy. Aust Soc Anaesth 1996;24:546-5I.

10. Forrest JB, Cahalan MK, Rehder K, Goldsmith $\mathrm{CH}$, Levy WJ, Strunin L, et al. Multicenter study of general anesthesia II. Results. Anesthesiology 1990;72:262-8.

I1. Palazzo MGA, Strunin L. Anaesthesia and emesis. I: etiology. Can Anaesth Soc J 1984; $31: 178-87$

12. Carvalho WA, Vianna PTG, Braz JRC. Náuseas e vômitos em anestesia: fisiopatologia e tratamento. Rev Bras Anestesiol 1999; 49(I):65-79.

13. Helmy SAK. Prophylactic anti-emetic efficacy of ondansetron in laparoscopic cholecystectomy under total intravenous anaesthesia. Anaesthesia 1999; 54:266-96.

14. Ku CM, Ong BC. Postoperative nausea and vomiting: a review of current literature. Singapore Med J 2003;44:366-74.

15. Hirsch J. Impact of postoperative nausea and vomiting an the surgical setting. Anaesthesia 1994:49(Suppl):30-3

16. Somri M, Vaida SJ, Sabo E, Yassain G, Gankin I, Gaitini LA. Acupunture versus ondansetron in the prevention of postoperative vomiting. A study of children undergoing dental surgery. Anaesthesia 200 I;56( I 0):927-32.

17. Harmon D, Ryan M, Kelly A, Bowen M. Acupressure and prevention of nausea and vomiting during and after spinal anaesthesia for caesarean section. $\mathrm{Br} J$ Anaesth 2000; 84(4):463-7.

18. Schlager A, Boehler M, Pühringer F. Korean hand acupressure reduces postoperative vomiting in children after strabismus surgery. $\mathrm{Br}$ J Anaesth 2000;85(2):267-70.

19. Zárate E, Mingus M, White PF, Chiu JW, Scuderi P, Loskota $W$, et al. The use of transcutaneous acupoint electrical stimulation for preventing nausea and vomiting after laparoscopic surgery. Anesth Analg 200I; 92:629-35.

20. Van den Berg AA. Comparison of ondansetron and prochlorperazine for the prevention of nausea and vomiting after adenotonsillectomy. $\mathrm{Br}$ J Anaesth 1996;76:449-5I.

21. Williams PI, Smith M. An assessment of prochlorperazine buccal for the prevention of nausea and vomiting during intravenous patient-controlled analgesia with morphine following abdominal hysterectomy. Eur J Anaesth 1999; 16(9):638-45.
22. Morgan RJ, Synold T, Carr BI, Doroshow JH, Womack EP, Shibata S, et al. Continuous infusion prochlorperazine: pharmacokinetics, antiemetic efficacy, and feasibility of high-dose therapy. Cancer Chemother Pharmacol 200 I;47(4):327-32.

23. Tarkkila P, Törn K, Tuominen M, Lindgren L. Premedication with promethazine and transdermal scopolamine reduces the incidence of nausea and vomiting after intratecal morphine. Acta Anaesthesiol Scand 1995;36:983-6.

24. Khalil S, Philbrook L, Rabb M, Wells L, Aves T, Villanueva G, et al. Ondansetron/prometazine combination or promethazine alone reduces nausea and vomiting after middle ear surgery. J Clin Anesth 1999; I 1:596-600.

25. Kreisler NS, Spiekermann BK, Ascari CM, Rhyne HA, Kloth RL, Sullivan LM, et al. Smalldose droperidol effectively reduces nausea in a general surgical adult patient population. Anesth Analg 2000;91: 1 256-61.

26. Desilva PH, Darvish AH, McDonald SM, Cronin MK, Clark K. The efficacy of prophylactic ondansetron, droperidol, perphenazine, and metoclopramide in the prevention of nausea and vomiting after major gynecologic surgery. Anesth Analg 1995;8 I ( I): I 39-43.

27. Steinbrook RA, Gosnell JL, Freiberger D. Prophylactic antiemetics for laparoscopic cholecystectomy: a comparison of perphenazine, droperidol plus ondansetron, and droperidol plus metoclopramide. J Clin Anesth 1998; 1 0(6):494-8.

28. Tornetta FJ. Antiemetic effectiveness of haloperidol in human volunteers challenged with apomorphine. Guest discussion. Anesth Analg 197|;50(6): 1024-9.

29. Tornetta FJ. Double-blind evaluation of haloperidol for antiemetic activity. Anaesth Analg 1972; 5 I (6):964-7.

30. Barton, Libonati M, Cohen PJ. The use of haloperidol for treatment of postoperative nausea and vomiting: a double-blind placebocontrolled trial. Anesthesiology 1975;42 (4):508-12.

31. Eberhart LHJ, Mauch M, Morin AM, Wulf H, GsIdner G. Impact of a multimodal anti-emetic prophylaxis on patient satisfaction in high-risk patients for postoperative nausea and vomiting. Anaesthesia 2002;57: 1 022-7.

32. Tornetta FJ. Comparison of droperidol, diazepam, and hydroxyzine hydrochloride as premedication. Anesth Analg 1977;56(4):496500.

33. Korttila K, Kauste A, Auvinen J. Comparison of domperidone, droperidol and metoclopramide in the prevention and treatment of nausea and vomiting after balanced general anesthesia. Anesthesia and Analgesia 1979; 58(5):396-400.

34. Abramowitz MD, Oh TH, Epstein BS, Ruttiman UE, Friendly DS. The antiemetic effect of droperidol following outpatient strabismus surgery in children. Anesthesiology 1983; 59: 579-83.

35. O'Donovan N, Shaw J. Nausea and vomiting in day-case dental anaesthesia: The use of 
low-dose droperidol. Anaesthesia 1984; 39(12): 1 172-6

36. Valanne J, Kortilla K. Effect of a small dose of droperidol on nausea, vomiting and recovery after outpatient enflurane anaesthesia. Acta Anaesth Scand 1985; 29(4):359-62.

37. Madej TH, Simpson KH. Comparison of the use of domperidone, droperidol and metoclopramide in the prevention of nausea and vomiting following major gynaecological surgery. Br J Anaesth 1986; 58(8):884-7.

38. Koivuranta M, Lara E, Ranta $P$, Ravaska $P$, Alahuhta S. Comparison of ondansetron and droperidol in the prevention of postoperative náusea and vomiting after laparoscopic surgery in women. Acta Anaesthesiol Scand 1997; 41:1273-9.

39. Bugedo G, Gonzalez J, Asenjo C, De la Cuadra JC, Gajardo A, Castillo L, et al. Ondansetron and droperidol in the prevention of postoperative nausea and vomiting. $\mathrm{Br}$ J Anaesth 1999;83:813-4.

40. Eberhart LHJ, Seeling W, Bopp TI, Morin AM, Georgieff M. Dimenhydrinate for prevention of pos-operative nausea and vomiting in female in-patients. Eur J Anaesthesiol 1999; 16 (5):284-9.

41. Welters ID, Menges T, Gräf M, Beikirch C, Menzebach A, Hempelmann G. Reduction os postoperative nausea and vomiting by dimenhydrinate suppositories after strabismus surgery in children. Anesth Analg 2000; 90(2):31 I-4.

42. Snow JC. Hydroxyzine for postoperative nausea and vomiting following ophthalmologic surgery. Anesth Analg 1965;44(5):487-91.

43. McKenzie R, Wadhwa RK, Uy NT, Phitayakorn P, Tantisira B, Sinchioco C, et al. Antiemetic effectiveness of intramuscular hydroxyzine compared with intramuscular droperidol. Anesth Analg 1981;60(I I):783-8.

44. Bonica JJ, Crepps W, Monk B, Bennett B. Postoperative nausea, retching and vomiting: evaluation of cyclizine (Marezine) suppositories for treatment. Anesthesiology 1958; 19:532-40.

45. Cholwill JM, Wright W, Hobbs GR, Curran J. Comparison of ondansetrona and cyclizine for prevention of nausea and vomiting after daycase gynaecological laparoscopy. $\mathrm{Br} J$ Anaesth 1999;83(4):61 I-4.

46. Grimsehl K, Whiteside JB, Mackenzie N. Comparison of cyclizine and ondansetron for the prevention of postoperative nausea and vomiting in day-case gynaecological surgery. Anaesthesia 2002;57:61-5.

47. Nortcliffe SA, Shah J, Buggy DJ. Prevention of postoperative nausea and vomiting after spinal morphine for caesarean section: comparison of cyclizine, dexamethasone and placebo. $\mathrm{Br}$ J Anaesth 2003;90(5):665-70.

48. Clissold SP, Heel RC. Transdermal hyoscine (Scopolamine): a preliminary review of its pharmacodynamic properties and therapeutic efficacy. Drugs 1985; 29(3): 189-207.

49. Aronson JK, Sear JW. Transdermal hyoscine (scopolamine) and postoperative vomiting. Anaesthesia 1986; 4I(I): I-3.
50. Kotelko DM, Rottman RL, Wright WC, Stone JJ, Yamashiro AY, Rosenblatt RM. Transdermal scopolamine decreases nausea and vomiting following cesarean section in patients receiving epidural morphine. Anesthesiology 1989; 7I (5):675-8.

5।. Justin-Besançon L, Laville C. Action antiémétique du métoclopramide vis-à-vis l'apomorphine et de l'hydergine. C R Seances Soc Biol (Paris) 1964; I 58:723-7.

52. Ellis FR, Spence AA. Clinical trials of metoclopramide (Maxolon) as an antiemetic in anaesthesia. Anaesthesia 1970;25(3):368-7I.

53. Pinder RM, Brogden RN, Sawyer PR, Speight TM, Avery GS. Metoclopramide: a review of its pharmacological properties and clinical use. Drugs 1976; 12(2):81-131.

54. Diamond MJ, Keeri-Szanto M, Reduction of postoperative vomiting by preoperative administration of oral metoclopramide. Can Anaesth Soc 1980; 27( I):36-9.

55. Gralla RJ. Metoclopramide. A review of antiemetics trials. Drugs 1983; 25(I):63-73.

56. Morris RW, Aune H, Feiss P, Hanson A, Hasselstrom L, Maltby JR, et al. International, multicenter, placebo-controlled study to evaluate the effectiveness of ondansetrona vs metoclopramide in the prevention of postoperative nausea and vomiting. Eur J Anaesthesiol 1998; 15(I):69-79

57. Fonseca NM, Cardoso RCGP. Prevenção de náuseas e vômitos com metoclopramida em pacientes submetidos à curetagem uterina sob anestesia geral. Rev Bras Anestesiol 200I; 5 I (2): I05- I I

58. Zegveld C, Knape H, Smits J, Belopavlovic M, Caron D, Gallant J, et al. Domperidone in the treatment of postoperative vomiting: a double blind multicenter study. Anesth Analg 1978;57:700-3

59. Fragen RJ, Caldwell N. Antiemetic effectiveness of intramuscularly administered domperidone. Anesthesiology 1979;5 I (5):460-I .

60. Brogden RN, Carmine AA, Heel RC, Speight TM, Avery GS. Domperidone: A review of its pharmacological activity, pharmacokinetics and therapeutic efficacy in the symptomatic treatment of chronic dyspepsia and as an antiemetic. Drugs 1982;24:360-400.

61. Champion MC, Hartnett M, Yen M. Domperidone, a new antagonist. Can Med Assoc J 1986; | 35(5):457-61.

62. Booij LHDJ, Rachmat S, Bulder ER. Alizapride in prevention of postoperative nausea and vomiting. Neth J Surg 1988;40:6-9.

63. Vanacker B, Van Aken K. Alizapride in the prevention of postoperative vomiting: $A$ double blind comparison. Acta Anaesthesiol Belg 1988;39(4):247-50.

64. Dani R, Coelho RCL. Efeito antiemético da alizaprida - avaliação multicêntrica de 1945 casos. Folha Med 1990; I 0 (3): I 93-202.

65. Stienstra R, Samhan YM, El-Mofty M, de Bont LEA, Bovill JG. Double-blind comparison of alizapride, droperidol and ondansetron in treatment of post-eeeeeeoperative nausea. Eur J Anaesthesiol 1997; | 4:290-4.
66. Roila F. Dexametasone, granisetron, or both for the prevention of nausea and vomiting during chemotherapy for cancer. N Engl J Med 1995;332: I-5.

67. Fuji $Y$, Sayito $Y$, Tanaka $H$, Toyooka $H$. Granisetron/dexamethasone combination for the prevention of postoperative nausea and vomiting after laparoscopy cholecystectomy. Eur J Anaesthesiol 2000; 17:64-8.

68. Goldman AC, Govindaraj S, Rosenfeld RM. A meta-analysis of dexamethasone use with tonsillectomy. Otolaryngol Head Neck Surg 2000; 123:682-6.

69. Henzi I, Walder B, Tramer MR. Dexamethasone for the prevention of postoperative nausea and vomiting: a quantitative systematic review. Anesth Analg 2000;90: I 86-94.

70. Thomas R, Jones N. Dexamethasone reduces nausea and vomiting after laparoscopy. $\mathrm{Br} J$ Anaesth 2000;85:328-9.

7I. Wang JJ, Ho ST, Lee SC, Liu YC, Ho CM. The use of dexamethasone for preventing postoperative nausea and vomiting in females undergoing thyroidectomy: a dose-ranging study. Anesth Analg 2000;9 I (6): I 040-7.

72. Wang JJ, Ho ST, Liu HS, Ho CM. Prophylactic antiemetic effect of dexamethasone in women undergoing ambulatory laparoscopic surgery. $\mathrm{Br}$ J Anaesth 2000;84:459-62.

73. Wang JJ, Ho ST, Tzeng JL, Tang CS. The effect of timing of dexamethasone administration on its efficacy as a prophylatic antiemetic for postoperative nausea and vomiting. Anesth Analg 2000;91: 136-9.

74. Aouad MT, Siddik SS, Rizk LB,Zaytoun GM, Baraka AS. The effect of dexamethasone on postoperative vomiting after tonsillectomy. Anesth Analg 200 I ;92(3):636-40.

75. Coloma M, Duffy LL, White PF, Kendall Tongier W, Huber PJ. Dexamethasone facilitates discharge after outpatient anorectal surgery. Anesth Analg $2001 ; 92(1): 85-8$.

76. Wang JJ, Ho ST, Wong CS, Tzeng JI, Liu HS, Ger LP. Dexamethasone prophilaxis of nausea and vomiting after peridural morphine for post-cesarean analgesia. Can J Anaesth 200I; 48(2): 185-90.

77. Rothenberg DM, Parnass SM, Litwack K, McCarthy RJ, Newman LM. Efficacy of ephedrine in the prevention of postoperative nausea and vomiting. Anesth Analg 1991; 72:58:61.

78. Doze VA, Shafer A, White PF. Propofolnotrous oxide versus thiopental-isofluranenitrous oxide for general anesthesia. Anesthesiology 1988;69:63-7।.

79. Korttila K, Östman P, Faure E, Apfelbaum JL, Prunskis J, Ekdawim M, et al. Randomized comparison of recovery after propofol-nitrous oxide versus thiopentone-isoflurane-nitrous oxide anaesthesia in patients undergoing ambulatory surgery. Acta Anaesthesiol Scand 1990;34:400-3.

80. Borgeat A, Wilder-Smith OHG, Saiah M, Rifat K. Subhypnotic doses of propofol possess direct antiemetic properties. Aanesth Analg 1992;74(4):539-41. 
81. Splinter WB, Rhine EJ, Roberts DJ. Vomiting after strabismus surgery in children: ondansetrona versus propofol. Can J Anaesth 1997;44(8):825-9.

82. McCollum JSC, Miligan KR, Dundee JW. The antiemetic action of propofol. Anaesthesia 1988:43:239-40.

83. Gan TJ, El-Molen H, Ray J, Glass PSA. A randomized, double-blind comparison of two doses of propofol versus placebo. Anesthesiology 1999;90: I 564-70.

84. Ganem EM, Fukushima FB, Silva DSM, Nakamura G, Castiglia YMM, Vianna PTG. Eficácia do propofol e da associação de porpofol e dexametasona no controle de náuseas e vômitos no pós-operatório de laparoscopia ginecológica. Rev Bras Anestesiol 2002;52(4):394-40I.

85. Alon E, Himmelseher S. Ondansetron in the treatment of postoperative vomiting: a randomized, double-blind comparison with droperidol and metoclopramide. Anesth Analg 1992;75:561-5.

86. Scuderi P, Wetchler B, Sung YF, Mingus M, DuPen S, Claybon L, et al. Treatment of postoperative nausea and vomiting after outpatient surgery with the $5-\mathrm{HT}_{3}$ antagonist ondansetron. Anesthesiology 1993;78: 15-20.

87. Furst SR, Rodarte A. Prophylactic antiemetic with ondansetrona in children undergoing tonsillectomy. Anesthesiology 1994;8I(4): 799-803.

88. Joslyn AF. Ondansetron, clinical development for postoperative nausea and vomiting: current studies and futures directions. Anaesthesia 1994:49(Suppl):34-7.

89. McKenzie R, KovacA, O'Connor T, Duncalf D, Angel J, Gratz I, et al. Comparison of ondansetron versus placebo to prevent postoperative náusea and vomiting in women undergoing ambulatory surgery. Anesthesiology 1993;78:21-8.

90. Chen PP, Chui PT, Gin T. Comparison of ondansetrona and metoclopramide for the prevention of post-operative nausea and vomiting after major gynaecological surgery. Eur J Anaesthesiol 1996; | 3:485-91.

91. Domino KB, Anderson EA, Polissar NL, Posner KL. Comparative efficacy and safety of ondansetron, droperidol, and metoclopramide for preventing postoperative nausea and vomiting: a meta-analysis. Anesth Analg 1999:88: 1370-9.

92. Figueredo E, Canosa L. Prophylatic ondansetron for postoperative emesis. Meta-analysis of its effectiveness in patients with previous history of post-operative nausea and vomiting. Acta Anaesthesiol Scand 1999;43:637-44.

93. Koivuranta M, Ala-kokko TI, Jokela R, Ranta P. Comparison of ondansetron and tropisetron combined with droperidol for the prevention of emesis in women with a history of postoperative nausea and vomiting. Eur J Anaesthesiol 1999;1 6:390-5.

94. Kovac AL, O'Connor TA, Perlman MH, Kekoler LJ, Edmondson D, Baughman VL, et al. Efficacy of repeat intravenous dosing of ondansetron in controlling postoperative nausea and vomiting: a randomized, doubleblind, placebo-controlled multicenter trial. J Clin Anaesth 1999; 1 1:453-9.

95. Sadhasivam S, Saxena A, Kathirvel S, Kannan TR, Trikha A, Mohan V. The safety and efficacy of prophylactic ondansetron in patients undergoing modified radical mastectomy. Anesth Analg 1999;89: 1340-5.

96. Tsui SL, Ng KF, Wong LC, Tang GW, Pun TC, Yang JC. Prevention of postoperative nausea and vomiting in gynaecological laparotomies: a comparison of tropisetron and ondansetron. Anaesth Intensive Care 1999;27:47|-6.

97. Warrick PD, Belo SE. Treating 'rebound' emesis following outpatient gynecologic laparoscopy: the efficacy of a two-dose regimen of droperidol and ondansetron. J Clin Anesth 1999; 1 1:1 19-25

98. Fujii $Y$, Saitoh $Y$, Tanaka $H$, Toyooka $H$. Preoperative oral antiemetics for reducing postoperative vomiting after tonsillectomy in children: granisetron versus perphenazine. Anesth Analg 1999;88: | 298-30 |

99. Fujii $Y$, Saitoh Y, Tanaka H, Toyooka H. Antiemetic efficacy of prophylactic granisetron compared with perphenazine for the prevention of post-operative vomiting in children. Eur J Ansesthesiol I 999; I 6(5):304-7.

100.Fujii Y, Saitoh Y, Tanaka H, Toyooka H. Ramosetron versus granisetron for the prevention of postoperative nausea and vomiting after laparoscopic cholecystectomy. Can J Anesth 1999:46:991-3.

I 0 I .Lee CR, Plosker GL, McTavish D. Tropisetron. A review of its phamacodynamic and pharmacokinetic properties, and therapeutic potential as an antiemetic. Drugs 1993;46(5):925-43.

102.Scholz J, Hennes HJ, Steinfath M, Färber L, Schweiger C, Dick W, et al. Tropisetron or ondansetron compared with placebo for prevention of postoperative nausea and vomiting. Eur J Anaesthesiol 1998; I 5:676-85.

103.Jokela R, Koivuranta M. Tropisetron or droperidol in the prevention of postoperative náusea and vomiting. Acta Anaesth Scand 1999;43:645-50.

104. Balfour JA, Goa KL. Dolasetron. A review of its pharmacology and therapeutic potential in the management of nausea and vomiting induced by chemotherapy, radiotherapy or surgery. Drugs 1997;54(2):273-98

105. Loewen PS, Marra CA, Zed PJ. 5-HT3 receptor antagonists vs traditional agents for the prophylaxis of postoperative nausea and vomiting. Can J Anaesth 2000; 47(10): 1008- 18

106.Fisher DM. The "big little problem" of postoperative nausea and vomiting. Do we know the answer yet ? Anesthesiology 1997;87: | 27|-3.

107. Hill RP, Lubarsky DA, Phillips-Bute B, Fortney JT, Creed MR, Glass PSA, et al. Cost-effectiveness of prophylactic antiemetic therapy with ondansetron, droperidol, or placebo. Anesthesiology 2000; 92:958-67.
108. Roila F, Del Fávero A. Ondansetron clinical pharmacokinetics. Clin Pharmacokinet 1995; $29(2): 95$.

109. Rojanasthien N, Manorot M, Kumsor NB. Pharmacokinetics and bioequivalence testing of generic ondansetron preparations in healthy Thai male volunteers. Int J Pharmacol Ther 1999;37( I I):548-54.

I I 0.Culy CR, Bhana N, Plosker GL. Ondansetron: a review of its use as an antiemetic in children. Paediatr Drugs 200 I;3(6):44I-79.

I I I.Gupta A, Wu CL, Elkassabany N, Krug CE, Parker SD, Fleisher LA. Does the routine prophylactit use of antiemetics affect the incidence of postdischarge nausea and vomiting following ambulatory surgery ? Anesthesiology 2003;99:488-95.

I 12.Leeser J, Lip H. Prevention of postoperative nausea and vomiting using ondansetrona, a new, selective, 5-HT3 receptor antagonist. Anesth Analg | 99|;72(6):75 |-5.

II3.Dupeyron JP, Conseiller C, Levarlet M, Hemmingsen C, Scheffer P, Pedersen FM, et al. The effect of oral ondansetrona in the prevention of postoperative nausea and vomiting after major gynaecological surgery performed under general anaesthesia. Anaesthesia 1993;48:214-8.

1|4.Rust M, Cohen LA. Single oral dose ondansetrona in the prevention of postoperative nausea and emesis. The European and US Study Groups. Anaesthesia 1994:49:16-23.

I 15.Rose JB, Brenn BR, Corddry DH, Thomas PC. Preoperative oral ondansetrona for pediatric tonsillectomy. Padiatr Anesth 1996;82:558-62.

I 1 6. Tramer MR, Reynolds DJ, Moore RA, McQuay $H J$. Efficacy, dose-response, and safety of ondansetrona in prevention of post-operative nausea and vomiting: a quantitative systematic review of randomized placebo-controlled trials. Anesthesiology 1997;87(6): I 277-89.

1 17.Gan TJ, Franiak R, Reeves J. Ondansetron orally disintegrating tablet versus placebo for the prevention of postdischarge náusea and vomiting after ambulatory surgery. Anesth Analg 2002;94: I 199-200.

I 18.Apfel CC, Greim CA, Goepfert C, Usadle J, Sefrin P, Roewer N. A risk score to predict the probability of postoperative vomiting in adults. Acta Anaesthesiol Scand I 998;42(5):495-50 I .

1 19. Blackwell CP, Harding SM. The clinical pharmacology of ondansetrona. Eur J Cancer Clin Oncol 1 989;25:S25-27.

120. Colthup PV, Felgate CC, Palmer JL, Scully NL. Determination of ondansetron in plasma and its pharmacokinetics in the young and elderly. J Pharm Sci 1991;80(9):868-71 .

Artigo recebido: 14/1 I/2003 Aceito para publicação: 16/01/2004 